\title{
Announcement
}

\section{WIPO Patent and Trademark Information Fair 1986}

The World Intellectual Property Organization is organizing a Patent and Trademark Information Fair which will be held at the International Conference Centre of Geneva (15, rue de Varembé), from Monday 8 September to Wednesday 10 September 1986.

The theme of this Fair, the second organized by WIPO, will be the role of computers in industrial property offices in their tasks concerning patents and trademarks. The Fair should, in particular, provide visitors with up-to-date information on the available or planned services for searching the technological information contained in patent documents and for the searching of data bases dealing with trademarks. The Fair will accordingly be of vital interest to research and development scientists, technical information specialists, as well as patent and trademark professionals.

The industrial property offices of the following countries have been invited to demonstrate their patent and trademark information services: Australia, Austria, Brazil, Canada, China, Czechoslovakia, Denmark, Finland, France, German Democratic Republic, Germany (Federal Republic of), Hungary, Japan, The Netherlands, Norway, Poland, Republic of Korea, Romania, Soviet Union, Spain, Sweden, Switzerland, the United Kingdom, and the United States of America. In addition, the European Patent Office has been invited.

The following producers and/or vendors of patent and trademark information have been invited to demonstrate their services: Bertelsmann Datenbankdienste $\mathrm{GmbH}$, Carl Heymanns Verlag, Chemical Abstracts Service, Compumark, Derwent Publications 1td., DIALOG Information Services inc., Engineering Information inc., Fachinformationszentrum Technik e.V., IFI/Plenum Data Company, Institution of Electrical Engineers (INSPEC), International Patent Documentation Center (INPADOC), Japan Patent Information Organization (JAPIO), Mead Data Central International, Pergamon-InfoLine ltd., Research Publications ltd., SDC Information Services inc., Télésystèmes-Questel S.A., and Thomson \& Thomson.

Admission to the Fair will be free. The Fair will be opened by the Director General of WIPO on Monday 8 September 1986, at 2 p.m. It will remain open on 
that day until 5 p.m. On the other two days of the Fair (9 and 10 September), it will open from 10 a.m. to 5 p.m.

Further information can be obtained from WIPO at: 34 chemin des Colombettes, 1211 Genève 20, Switzerland; tel. (022) 999-111; telex 22376 ch. 